\title{
Pontibacter korlensis sp. nov., isolated from the desert of Xinjiang, China
}

\author{
Lei Zhang,† Qiuju Zhang,† Xuesong Luo, Yali Tang, Jun Dai, Yaowei Li, \\ Yang Wang, Gong Chen and Chengxiang Fang
}

Correspondence

Chengxiang Fang

cxfang@whu.edu.cn
College of Life Sciences, Wuhan University, Wuhan 430072, PR China

Two Gram-negative, rod-shaped, gliding and pink-pigmented bacterial strains, $\mathrm{X} 14-1^{\top}$ and X19-1, were isolated from a mixture of sand samples collected from the desert of Xinjiang, China, and characterized by using a polyphasic taxonomic approach. Strains $X 14-1^{\top}$ and $X 19-1$ contained MK-7 as the predominant menaquinone. The major cellular fatty acids included iso- $\mathrm{C}_{15: 0}$, iso- $\mathrm{C}_{17: 0} 3-\mathrm{OH}$, summed feature 3 and summed feature 4 . The DNA $\mathrm{G}+\mathrm{C}$ contents of strains $\mathrm{X} 14-1^{\top}$ and $\mathrm{X} 19-1$ were 48.2 and 48.9 mol\%, respectively. $16 \mathrm{~S}$ rRNA gene sequence analysis showed that the isolates were highly related to each other (99.2\%) and confirmed their placement in the genus Pontibacter. Strains X14-1 ${ }^{\top}$ and X19-1 exhibited 16S rRNA gene similarity levels of 95.0-97.2\% to the type strains of the two Pontibacter species with validly published names. DNA-DNA hybridization experiments revealed a high level of relatedness between the two new isolates ( $82 \%$ ), but low levels of relatedness between strain $\mathrm{X} 14-1^{\top}$ and the phylogenetically most closely related species Pontibacter actiniarum KMM $6156^{\top}(51 \%)$. On the basis of genotypic and phenotypic evidence, strains $X 14-1^{\top}$ and $X 19-1$ are considered to represent a novel species of the genus Pontibacter, for which the name Pontibacter korlensis sp. nov. is proposed. The type strain is $\mathrm{X} 14-1^{\top}\left(=\right.$ CCTCC AB $206081^{\top}=$ NRRL B-51097 $\left.{ }^{\top}\right)$.
The genus Pontibacter belongs to the phylum Bacteroidetes and currently comprises two species: Pontibacter actiniarum and Pontibacter akesuensis (Nedashkovskaya et al., 2005; Zhou et al., 2007). The type strains of the recognized species of the genus are Gram-negative, aerobic, heterotrophic and pink-pigmented bacteria. These Pontibacter species were isolated from marine actinians and desert soil, respectively. In this study, we report on the taxonomic characterization of two pink-pigmented bacterial strains, X14- $1^{\mathrm{T}}$ and X19-1, which were isolated from a desert soil sample from Xinjiang Province, China.

Strains $\mathrm{X} 14-1^{\mathrm{T}}$ and X19-1 were isolated by using the standard dilution plating technique at $30{ }^{\circ} \mathrm{C}$ on $0.1 \times$ tryptic soy broth (TSB) agar plates (Difco). However, the isolates grew better on marine agar 2216 (Difco). The results of a polyphasic taxonomic study of the isolates indicated that they represent a novel species of the genus Pontibacter.

†These authors contributed equally to this work.

The GenBank/EMBL/DDBJ accession numbers for the 16S rRNA gene sequences of strains $\times 14-1^{\top}$ and $\times 19-1$ are 00888330 and D0888331, respectively.

A transmission electron micrograph of cells of strain $X 14-1^{\top}$ is available as a supplementary figure with the online version of this paper.
Cell morphology was examined by phase-contrast microscopy (Olympus) and by transmission electron microscopy. Gram staining of cells was carried out according to the classical Gram procedure described by Doetsch (1981). Gliding motility was determined as described by Bowman (2000). Oxidase activity was determined using a $1 \%$ solution of tetramethyl-p-phenylenediamine (Kovács, 1956). Catalase activity was determined by assessing the production of bubbles after the addition of a drop of $3 \%$ $\mathrm{H}_{2} \mathrm{O}_{2}$. Growth at different temperatures $(4,7,28,37,42$ and $\left.45{ }^{\circ} \mathrm{C}\right), \mathrm{pH}(4-11)$ and $\mathrm{NaCl}$ concentration $(0-10 \%$, $\mathrm{w} / \mathrm{v})$ was investigated on $0.1 \times \mathrm{TSB}$ agar for up to 1 week. Some conventional biochemical tests were performed as described by Smibert \& Krieg (1994), including tests for Tween 40, Tween 80, starch and casein hydrolysis. Physiological and biochemical features of strains X14-1 ${ }^{\mathrm{T}}$ and X19-1 were also determined using the API 20E, API 20NE, API ZYM (bioMérieux) and Biolog GN2 Microplate system (Biolog) according to the manufacturers' instructions. Antimicrobial susceptibility testing was performed by using the agar-diffusion method with antibioticimpregnated discs, as described by Buczolits et al. (2002).

For 16S rRNA gene sequencing and phylogenetic analysis, DNA was extracted by using a Bacteria Genomic DNA Isolation kit (ChaoShi-Bio; China). PCR and 16S rRNA gene sequencing were carried out as described by Lin $e t$ al. 
(2004). Phylogenetic analysis was performed by using MEGA, version 3.1 (Kumar et al., 2004), after multiple alignment of the data via CLUSTAL_X (Thompson et al., 1997). Phylogenetic distances were calculated using the Kimura two-parameter model (Kimura, 1980) and clustering was performed by using the neighbour-joining method (Saitou \& Nei, 1987). Bootstrap analysis based on 1000 replications was undertaken to test the robustness of the phylogenetic tree (Felsenstein, 1985).

For DNA-DNA hybridization experiments and determination of the DNA G+C content, genomic DNA of the bacterial strains was prepared according to a modification of the procedure of Wilson (1987). The DNA G+C content was determined by HPLC according to the method of Mesbah et al. (1989). DNA-DNA hybridizations were performed using the microplate method, as described previously by Ezaki et al. (1989) and Willems et al. (2001). The respiratory quinone system was extracted and determined by HPLC as described by Xie \& Yokota (2003). For the determination of the whole-cell fatty acid profiles, strains X14- $1^{\mathrm{T}}$ and X19-1 and P. actiniarum KMM $6156^{\mathrm{T}}$ and $P$. akesuensis AKS $1^{\mathrm{T}}$ were grown at $30^{\circ} \mathrm{C}$ for $48 \mathrm{~h}$ on marine agar. Analysis of the fatty acid methyl esters was carried out according to the standard protocol of the Sherlock Microbial Identification System (MIDI).

Cells of strains X14-1 ${ }^{\mathrm{T}}$ and X19-1 were collected for morphological observations after being cultured on marine agar for $24 \mathrm{~h}$. The cells of the two strains were Gramnegative, rod-shaped and motile by gliding. Cells were prepared for transmission electron microscopy as described by Golyshina et al. (2000). Cells of strains X14-1 ${ }^{\mathrm{T}}$ and X191 ranged from 0.6 to $0.7 \mu \mathrm{m}$ in width and from 1.3 to $3.5 \mu \mathrm{m}$ in length (see Supplementary Fig. S1, available in IJSEM Online).

The 16S rRNA genes of strains X14- $1^{\mathrm{T}}$ and X19-1 showed a high level of similarity (99.2\%). Phylogenetic analysis based on 16S rRNA gene sequences showed that the new isolates were phylogenetically most related to the genera
Pontibacter and Effluviibacter (Fig. 1). P. actiniarum KMM $6156^{\mathrm{T}}$ was the closest relative of strains X14-1 ${ }^{\mathrm{T}}$ and X19-1. Similarity values between the $16 \mathrm{~S}$ rRNA gene sequences of the two isolates and P. actiniarum KMM $6156^{\mathrm{T}}$ were 97.2 and $96.8 \%$, respectively. No other recognized bacterial species showed more than $96 \% 16 \mathrm{~S}$ rRNA gene sequence similarity to the new isolates. Therefore, the two isolates appeared to belong to the genus Pontibacter.

The chemotaxonomic properties, i.e. fatty acid profiles and DNA G + C content, supported the result of the monothetic phylogenetic classification; namely, that the two isolates are members of the genus Pontibacter, and not the genus Effluviibacter (Nedashkovskaya et al., 2005; Suresh et al., 2006; Zhou et al., 2007). The two strains contained large amounts of branched-chain saturated and unsaturated fatty acids; the predominant fatty acids were iso$\mathrm{C}_{15: 0}$, iso- $\mathrm{C}_{17: 0} 3-\mathrm{OH}$, summed feature 3 (comprising $\mathrm{C}_{16: 1} \omega 7 c$ and/or iso- $\mathrm{C}_{15: 0} 2-\mathrm{OH}$ ) and summed feature 4 (consisting of anteiso- $\mathrm{C}_{17: 1} \mathrm{~B}$ and/or iso- $\mathrm{C}_{17: 1} \mathrm{I}$ ) (Table 1). These fatty acid profiles were similar to those of recognized Pontibacter species. The DNA G $+\mathrm{C}$ contents of strains X14- $1^{\mathrm{T}}$ and X19-1 were 48.2 and 48.9 mol\%, respectively.

Levels of DNA-DNA relatedness were determined between strain X14- $1^{\mathrm{T}}$ and the type strain of the phylogenetically most closely related species (P. actiniarum KMM $6156^{\mathrm{T}}$ ) and between strains X14-1 ${ }^{\mathrm{T}}$ and X19-1. Strains X14-1 ${ }^{\mathrm{T}}$ and X19-1 showed a level of DNA-DNA relatedness of $82 \%$, above the level of $70 \%$ that is accepted as the limit for species delineation (Wayne et al., 1987). Strain X14- ${ }^{\mathrm{T}}$ clearly showed $<70 \%$ DNA-DNA reassociation $(51 \%)$ with the closest neighbour, P. actiniarum KMM $6156^{\mathrm{T}}$. The results of the DNA-DNA hybridization experiments indicate that strains X14- $1^{\mathrm{T}}$ and X19-1 represent a single novel species of the genus Pontibacter.

The main physiological and biochemical characteristics of strains X14- $1^{\mathrm{T}}$ and X19-1 are given in Table 2 and the species description. The features that differentiate strains X14- $1^{\mathrm{T}}$ and X19-1 from related members of the genera

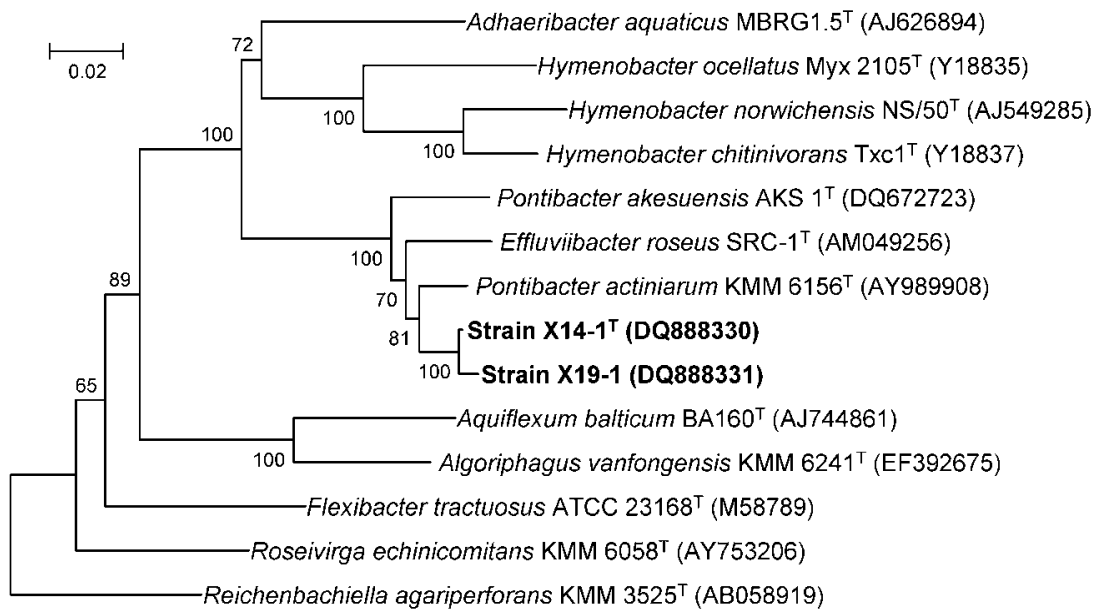

Fig. 1. Neighbour-joining phylogenetic tree, based on 16S rRNA gene sequences, showing the positions of strains $\mathrm{X} 14-1^{\top}$ and $\mathrm{X} 19-1$ and some other related taxa. Percentage bootstrap values (1000 replications) greater than $50 \%$ are shown at nodes. Reichenbachiella agariperforans KMM $3525^{\top}$ was used as the outgroup. Bar, 0.02 substitutions per nucleotide position. 
Table 1. Cellular fatty acid compositions (\%) of strains $\mathrm{X} 14-1^{\top}$ and $\mathrm{X} 19-1$ (Pontibacter korlensis sp. nov.) and closely related strains

Strains: 1 , X14-1 ${ }^{\mathrm{T}}$; 2, X19-1; 3, P. actiniarum KMM $6156^{\mathrm{T}}$; 4, P. akesuensis AKS $1^{\mathrm{T}}$; 5 , E. roseus SRC-1 ${ }^{\mathrm{T}}$. All data for Pontibacter species were taken from this study. Data for E. roseus SRC-1 ${ }^{\mathrm{T}}$ were taken from Suresh et al. (2006). Only fatty acids that account for more than $1 \%$ for one of the strains are indicated. ND, Not detected/ not reported.

\begin{tabular}{|c|c|c|c|c|c|}
\hline Fatty acid & 1 & 2 & 3 & 4 & 5 \\
\hline iso- $\mathrm{C}_{15: 1} \mathrm{~F}$ & 0.5 & 0.6 & $\mathrm{ND}$ & 1.2 & $\mathrm{ND}$ \\
\hline iso- $\mathrm{C}_{15: 0}$ & 15.0 & 15.8 & 22.8 & 22.8 & 15.8 \\
\hline anteiso- $\mathrm{C}_{15: 0}$ & 0.3 & 0.4 & 0.2 & 0.7 & 3.5 \\
\hline $\mathrm{C}_{15: 1} \omega 6 c$ & 1.1 & 0.9 & 0.4 & 3.1 & ND \\
\hline iso- $\mathrm{C}_{16: 1} \mathrm{H}$ & 1.3 & 1.0 & 0.3 & 2.8 & 4.4 \\
\hline iso- $\mathrm{C}_{16: 0}$ & 1.1 & 0.9 & 0.3 & 2.0 & 5.9 \\
\hline $\mathrm{C}_{16: 1} \omega 5 c$ & 0.9 & 1.0 & 0.7 & 1.2 & 2.1 \\
\hline$C_{16: 0}$ & 0.4 & 0.4 & 0.3 & 1.3 & 1.7 \\
\hline iso- $\mathrm{C}_{15: 0} 3-\mathrm{OH}$ & 2.6 & 2.7 & 2.6 & 2.7 & 2.4 \\
\hline iso- $\mathrm{C}_{17: 1} \omega 9 c$ & 0.3 & 0.3 & 0.2 & 1.1 & 1.0 \\
\hline iso- $\mathrm{C}_{17: 0}$ & 1.9 & 2.0 & 1.3 & 1.2 & 1.3 \\
\hline anteiso- $\mathrm{C}_{17: 0}$ & 0.1 & 0.2 & ND & ND & 1.3 \\
\hline $\mathrm{C}_{17: 1} \omega 6 c$ & 6.2 & 6.0 & 1.6 & 2.9 & 5.6 \\
\hline iso- $\mathrm{C}_{16: 0} 3-\mathrm{OH}$ & 0.4 & 0.4 & ND & 0.5 & 1.2 \\
\hline iso- $\mathrm{C}_{18: 1} \mathrm{H}$ & 0.3 & 0.3 & $\mathrm{ND}$ & 0.2 & 3.1 \\
\hline $\mathrm{C}_{16: 0} 3-\mathrm{OH}$ & $\mathrm{ND}$ & $\mathrm{ND}$ & ND & 0.1 & 1.3 \\
\hline $\mathrm{C}_{18: 1} \omega 9 c$ & 1.8 & 1.3 & 2.0 & 1.3 & $\mathrm{ND}$ \\
\hline $\mathrm{C}_{18: 1} \omega 7 c$ & 1.2 & 0.8 & 1.3 & 0.9 & $\mathrm{ND}$ \\
\hline $\mathrm{C}_{18: 0}$ & 1.2 & 0.9 & 1.4 & 2.3 & $\mathrm{ND}$ \\
\hline iso- $\mathrm{C}_{17: 0} 3-\mathrm{OH}$ & 9.6 & 10.1 & 6.2 & 6.9 & 10.3 \\
\hline \multicolumn{6}{|l|}{ Summed features ${ }^{\star}$} \\
\hline 2 & 1.7 & 1.9 & 2.5 & 6.0 & ND \\
\hline 3 & 10.3 & 11.3 & 16.2 & 4.2 & $\mathrm{ND}$ \\
\hline 4 & 33.4 & 33.4 & 31.4 & 26.7 & 36.7 \\
\hline 5 & 1.6 & 1.6 & 2.2 & 1.7 & ND \\
\hline
\end{tabular}

Summed features represent groups of two or three fatty acids that could not be separated using gas-liquid chromatography with the MIDI system. Summed feature 2 contains $\mathrm{C}_{13: 0} 3-\mathrm{OH}$ and/or iso- $\mathrm{C}_{15: 1} \mathrm{I}$; summed feature 3 contains $\mathrm{C}_{16: 1} \omega 7 c$ and/or iso- $\mathrm{C}_{15: 0} 2-\mathrm{OH}$; summed feature 4 contains anteiso- $\mathrm{C}_{17: 1} \mathrm{~B}$ and/or iso$\mathrm{C}_{17: 1} \mathrm{I}$; summed feature 5 contains anteiso- $\mathrm{C}_{18: 0}$ and/or $\mathrm{C}_{18: 2} \omega 6,9 c$.

Pontibacter and Effluviibacter are shown in Table 2. The results of the phenotypic examination showed that the strains studied have many traits in common with $P$. actiniarum KMM $6156^{\mathrm{T}}$. However, the habitats occupied by these two taxa are different: strains X14- ${ }^{\mathrm{T}}$ and X19-1 were isolated from desert soil samples, whereas $P$. actiniarum KMM $6156^{\mathrm{T}}$ was isolated from a marine habitat. In contrast to $P$. actiniarum $\mathrm{KMM} 6156^{\mathrm{T}}$, strains X14- $1^{\mathrm{T}}$ and X19-1 could hydrolyse starch, and utilize carbohydrates such as D-fructose, D-galactose and Dmannose as the sole carbon source. Strains $\mathrm{X} 14-1^{\mathrm{T}}$ and X19-1 produced enzymes such as $\alpha$-galactosidase and $\beta$ glucosidase, whereas $P$. actiniarum KMM $6156^{\mathrm{T}}$ produced trypsin, but not $\alpha$-galactosidase or $\beta$-glucosidase. Differences were also observed in the cellular fatty acid compositions of the novel strains and the two recognized Pontibacter species (Table 1).
Based on the phenotypic and genotypic evidence presented, strains X14- $1^{\mathrm{T}}$ and X19-1 should be assigned to the genus Pontibacter as representing a single novel species, for which the name Pontibacter korlensis sp. nov. is proposed.

\section{Description of Pontibacter korlensis sp. nov.}

Pontibacter korlensis (ko.r.len'sis. N.L. masc. adj. korlensis pertaining to Korla, a city of Xinjiang Province in the north-west of China from where the type strain was isolated).

Cells are Gram-negative, rod-shaped, motile by gliding, 1.3-3.5 $\mu \mathrm{m}$ long and $0.6-0.7 \mu \mathrm{m}$ wide. Colonies are circular, 2-3 $\mathrm{mm}$ in diameter, convex, shiny, pink and smooth on marine agar. Does not require $\mathrm{Na}^{+}$or seawater for growth. Growth occurs at $7-45^{\circ} \mathrm{C}$; optimal temperature for growth is $30-37{ }^{\circ} \mathrm{C}$. Growth occurs in $0-8 \%$ 
Table 2. Phenotypic characteristics that differentiate strains $X 14-1^{\top}$ and $X 19-1$ (Pontibacter korlensis sp. nov.) from related members of the genera Pontibacter and Effluviibacter

Strains: $1, \mathrm{X} 14-1^{\mathrm{T}}$ and X19-1; 2, P. actiniarum KMM $6156^{\mathrm{T}} ; 3$, P. akesuensis AKS $1^{\mathrm{T}} ; 4$, E. roseus SRC- $1^{\mathrm{T}}$. Data were taken from Nedashkovskaya et al. (2005), Suresh et al. (2006), Zhou et al. (2007) and this study. +, Positive; -, negative; NR, not reported.

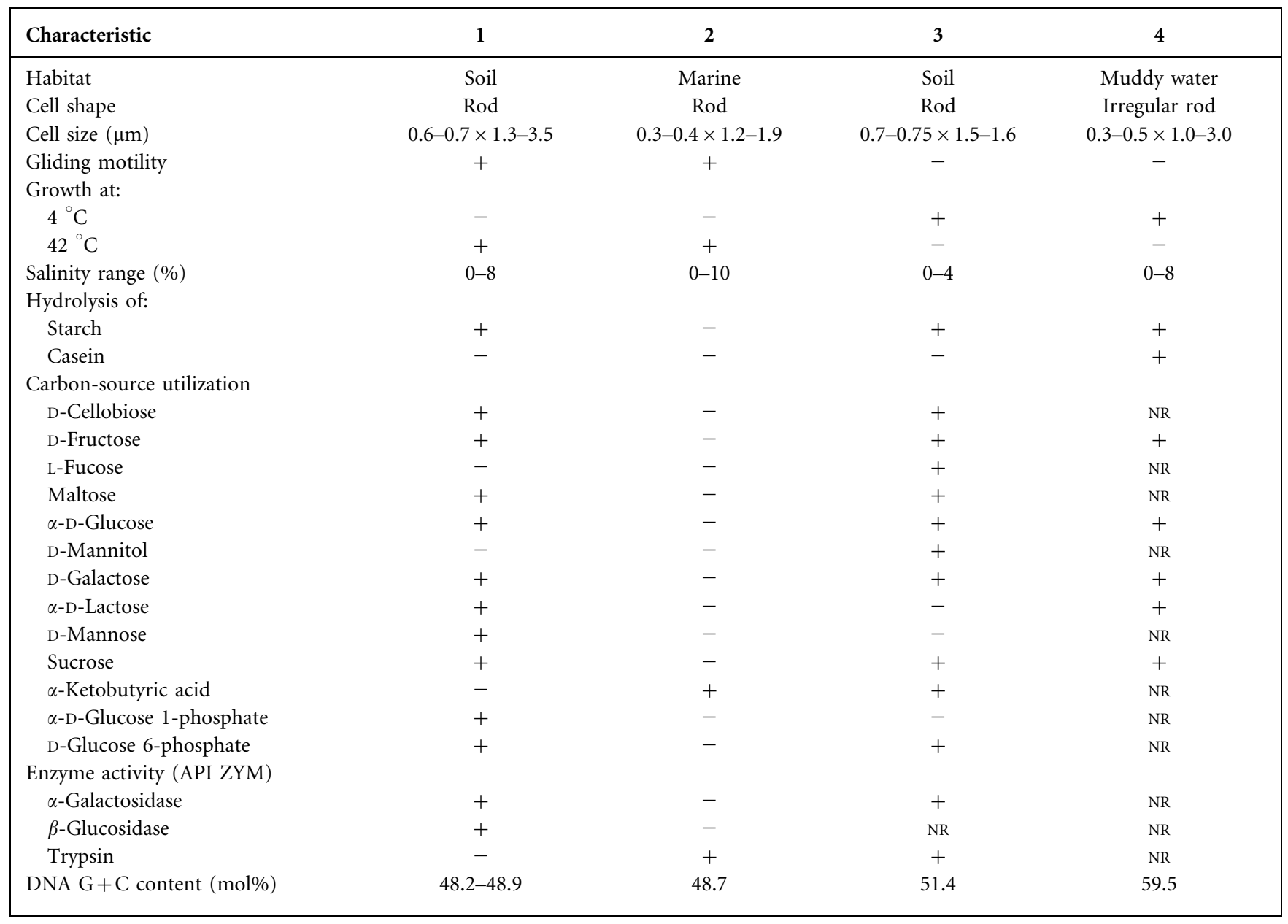

$\mathrm{NaCl}$ and at $\mathrm{pH}$ 5.5-11.0, with optimal growth at $\mathrm{pH} 7.0$ 8.0. Pigment can be extracted with organic solvents. Oxidase- and catalase-positive. Gelatin, aesculin and starch are decomposed, but casein and Tweens 40 and 80 are not hydrolysed. Nitrate reduction, $\mathrm{H}_{2} \mathrm{~S}$ production, citrate utilization, indole production and urease are negative. In Biolog GN2 tests, dextrin, glycogen, $N$-acetyl-D-glucosamine, L-arabinose, D-cellobiose, D-fructose, D-galactose, gentiobiose, $\alpha$-D-glucose, $\alpha$-D-lactose, lactulose, maltose, $\mathrm{D}$ mannose, $\mathrm{D}$-melibiose, methyl $\beta$-D-glucoside, $\mathrm{D}$-psicose, $\mathrm{D}$ raffinose, sucrose, trehalose, turanose, succinic acid monomethyl ester, acetic acid, $\alpha$-ketovaleric acid, DL-lactic acid, succinic acid, succinamic acid, L-alaninamide, Lalanine, L-asparagine, L-aspartic acid, L-glutamic acid, urocanic acid, $\alpha$-D-glucose 1-phosphate and D-glucose 6phosphate are utilized. Does not utilize $\alpha$-cyclodextrin, Tween 40, Tween 80, $N$-acetyl-D-galactosamine, adonitol, D-arabitol, i-erythritol, L-fucose, myo-inositol, D-mannitol, L-rhamnose, xylitol, pyruvic acid methyl ester, cis-aconitic acid, citric acid, formic acid, D-galactonic acid lactone,
D-galacturonic acid, D-gluconic acid, D-glucosaminic acid, D-glucuronic acid, $\alpha$-, $\beta$ - and $\gamma$-hydroxybutyric acids, phydroxyphenylacetic acid, itaconic acid, $\alpha$-ketobutyric acid, malonic acid, propionic acid, quinic acid, D-saccharic acid, sebacic acid, bromosuccinic acid, glucuronamide, Dalanine, glycyl L-aspartic acid, glycyl L-glutamic acid, Lhistidine, hydroxy-L-proline, L-leucine, L-phenylalanine, L-proline, L-pyroglutamic acid, D-serine, L-serine, L-threonine, DL-carnitine, $\gamma$-aminobutyric acid, inosine, uridine, thymidine, phenylethylamine, putrescine, 2-aminoethanol, 2,3-butanediol, glycerol or DL- $\alpha$-glycerol phosphate. According to the API ZYM gallery, produces alkaline phosphatase, esterase (C4), esterase lipase (C8), lipase (C14), leucine arylamidase, valine arylamidase, cystine arylamidase, acid phosphatase, naphthol-AS-BI-phosphohydrolase, $\alpha$-galactosidase, $\beta$-galactosidase, $\alpha$-glucosidase, $\beta$-glucosidase and $N$-acetyl- $\beta$-glucosaminidase, but not trypsin, $\alpha$-chymotrypsin, $\beta$-glucuronidase, $\alpha$-mannosidase or $\alpha$-fucosidase. Susceptible to chloramphenicol, colistin sulfate, erythromycin, gentamicin, penicillin $G$, polymyxin 
B sulfate, tetracycline and vancomycin. Resistant to kanamycin and streptomycin. The predominant menaquinone is MK-7. Major fatty acids are iso- $\mathrm{C}_{15: 0}$, iso- $\mathrm{C}_{17: 0}$ $3-\mathrm{OH}$, summed feature 3 (comprising $\mathrm{C}_{16: 1} \omega 7 c$ and/or iso$\mathrm{C}_{15: 0}$ 2-OH) and summed feature 4 (consisting of anteiso$\mathrm{C}_{17: 1} \mathrm{~B}$ and/or iso- $\mathrm{C}_{17: 1} \mathrm{I}$ ). The DNA $\mathrm{G}+\mathrm{C}$ content of the type strain is $48.2 \mathrm{~mol} \%$.

The type strain, X14- $1^{\mathrm{T}}$ (=CCTCC AB $206081^{\mathrm{T}}=$ NRRL B-5 $1097^{\mathrm{T}}$ ), was isolated from the surface layer of a desert soil from Korla, Xinjiang Province, China. Strain X19-1 is a reference strain.

\section{Acknowledgements}

We are grateful to Dr Olga I. Nedashkovskaya, Pacific Institute of Bioorganic Chemistry of the Far-Eastern Branch of the Russian Academy of Science, for providing the type strain of Pontibacter actiniarum. This work was supported by the R\&D Infrastructure and Facility Development Program from the Ministry of Science and Technology of the People's Republic of China (Grant No.2005DKA21208).

\section{References}

Bowman, J. P. (2000). Description of Cellulophaga algicola sp. nov., isolated from the surfaces of Antarctic algae, and reclassification of Cytophaga uliginosa (ZoBell and Upham 1944) Reichenbach 1989 as Cellulophaga uliginosa comb. nov. Int J Syst Evol Microbiol 50, 1861-1868.

Buczolits, S., Denner, E. B. M., Vybiral, D., Wieser, M., Kämpfer, P. \& Busse, H.-J. (2002). Classification of three airborne bacteria and proposal of Hymenobacter aerophilus sp. nov. Int J Syst Evol Microbiol 52, 445-456.

Doetsch, R. N. (1981). Determinative methods of light microscopy. In Manual of Methods for General Bacteriology, pp. 21-33. Edited by P. Gerdhardt, R. G. E. Murray, R. N. Costilow, E. W. Nester, W. A. Wood, N. R. Krieg \& G. B. Phillips. Washington, DC: American Society for Microbiology.

Ezaki, T., Hashimoto, Y. \& Yabuuchi, E. (1989). Fluorometric deoxyribonucleic acid-deoxyribonucleic acid hybridization in microdilution wells as an alternative to membrane filter hybridization in which radioisotopes are used to determine genetic relatedness among bacterial strains. Int J Syst Bacteriol 39, 224-229.

Felsenstein, J. (1985). Confidence limits on phylogenies: an approach using the bootstrap. Evolution 39, 783-791.

Golyshina, O. V., Pivovarova, T. A., Karavaiko, G. I., Kondrat'eva, T. F., Moore, E. R. B., Abraham, W.-R., Lünsdorf, H., Timmis, K. N., Yakimov, M. M. \& Golyshin, P. N. (2000). Ferroplasma acidiphilum gen. nov., sp. nov., an acidophilic, autotrophic, ferrous-iron-oxidizing, cellwall-lacking, mesophilic member of the Ferroplasmaceae fam. nov., comprising a distinct lineage of the Archaea. Int J Syst Evol Microbiol 50, 997-1006.

Kimura, M. (1980). A simple method for estimating evolutionary rates of base substitutions through comparative studies of nucleotide sequences. J Mol Evol 16, 111-120.
Kovács, N. (1956). Identification of Pseudomonas pyocyanea by the oxidase reaction. Nature 178, 703-704.

Kumar, S., Tamura, K. \& Nei, M. (2004). MEGA3: integrated software for Molecular Evolutionary Genetics Analysis and sequence alignment. Brief Bioinform 5, 150-163.

Lin, Y.-C., Uemori, K., de Briel, D. A., Arunpairojana, V. \& Yokota, A. (2004). Zimmermannella helvola gen. nov., sp. nov., Zimmermannella alba sp. nov., Zimmermannella bifida sp. nov., Zimmermannella faecalis sp. nov. and Leucobacter albus sp. nov., novel members of the family Microbacteriaceae. Int J Syst Evol Microbiol 54, 1669-1676.

Mesbah, M., Premachandran, U. \& Whitman, W. B. (1989). Precise measurement of the $\mathrm{G}+\mathrm{C}$ content of deoxyribonucleic acid by high-performance liquid chromatography. Int J Syst Bacteriol 39, 159-167.

Nedashkovskaya, O. I., Kim, S. B., Suzuki, M., Shevchenko, L. S., Lee, M. S., Lee, K. H., Park, M. S., Frolova, G. M., Oh, H. W. \& other authors (2005). Pontibacter actiniarum gen. nov., sp. nov., a novel member of the phylum 'Bacteroidetes', and proposal of Reichenbachiella gen. nov. as a replacement for the illegitimate prokaryotic generic name Reichenbachia Nedashkovskaya et al. 2003. Int J Syst Evol Microbiol 55, 2583-2588.

Saitou, N. \& Nei, M. (1987). The neighbor-joining method: a new method for reconstructing phylogenetic trees. Mol Biol Evol 4, 406-425.

Smibert, R. M. \& Krieg, N. R. (1994). Phenotypic characterization. In Methods for General and Molecular Bacteriology, pp. 607-654. Edited by P. Gerhardt, R. G. E. Murray, W. A. Woods \& N. R. Krieg. Washington, DC: American Society for Microbiology.

Suresh, K., Mayilraj, S. \& Chakrabarti, T. (2006). Effluviibacter roseus gen. nov., sp. nov., isolated from muddy water, belonging to the family "Flexibacteraceae". Int J Syst Evol Microbiol 56, 1703-1707.

Thompson, J. D., Gibson, T. J., Plewniak, F., Jeanmougin, F. \& Higgins, D. G. (1997). The CLUSTAL_X windows interface: flexible strategies for multiple sequence alignment aided by quality analysis tools. Nucleic Acids Res 25, 4876-4882.

Wayne, L. G., Brenner, D. J., Colwell, R. R., Grimont, P. A. D., Kandler, O., Krichevsky, M. I., Moore, L. H., Moore, W. E. C., Murray, R. G. E. \& other authors (1987). International Committee on Systematic Bacteriology. Report of the ad hoc committee on reconciliation of approaches to bacterial systematics. Int J Syst Bacteriol 37, 463-464.

Willems, A., Doignon-Bourcier, F., Goris, J., Coopman, R., de Lajudie, P., De Vos, P. \& Gillis, M. (2001). DNA-DNA hybridization study of Bradyrhizobium strains. Int J Syst Evol Microbiol 51, $1315-1322$.

Wilson, K. (1987). Preparation of genomic DNA from bacteria. In Current Protocols in Molecular Biology, pp. 2.4.1-2.4.5. Edited by F. M. Ausubel, R. Brent, R. E. Kingston, D. D. Moore, J. G. Seidman, J. A. Smith \& K. Struhl. New York: Greene Publishing and WileyInterscience.

Xie, C. H. \& Yokota, A. (2003). Phylogenetic analysis of Lampropedia hyalina based on the 16S rRNA gene sequence. J Gen Appl Microbiol 49, 345-349.

Zhou, Y., Wang, X., Liu, H., Zhang, K. Y., Zhang, Y. Q., Lai, R. \& Li, W. J. (2007). Pontibacter akesuensis sp. nov., isolated from a desert soil in China. Int J Syst Evol Microbiol 57, 321-325. 